\title{
爆発火炎の粒子ベースビジュアルシミュレーション法
}

\author{
竹下大樹 $\dagger$ 太田真 田村真智子 $\ddagger$ 藤本忠博 $\dagger$ 村岡一信 $*$ 千葉則茂 \\ †岩手大学 ‡(株)岩手ソフトウェアセンター *東北工業大学
}

\section{Particle-Based Visual Simulation of Explosive Flames}

Daiki Takeshita† Shin Otał Machiko Tamurał Tadahiro Fujimoto† Kazunobu Muraoka* Norishige Chiba† $\dagger$ Iwate University $\ddagger$ Iwate Software Center Inc. $*$ Tohoku Institute of Technology

take@cis.iwate-u.ac.jp; shin@isop.ne.jp; mati@isop.ne.jp; fujimoto@cis.iwate-u.ac.jp; muraoka@tohtech.ac.jp;nchiba@cis.iwate-u.ac.jp

アブストラクト

本論文では，粒子ベースによる爆発火炎のビジュアルシミュレーション法を提案する．本手法は，粒子による離散的なラグランジュ記述 による流体モデルに基づく数值シミュレーション法と, 弚の粒子群の運動データから CG 映像を生成するためのレンダリング法からなる . 本流体モデルでは，炎粒子と空気粒子を用い，ナビエ・ストークス方程式における外力として温度差による浮力を，また粘性力と圧力は粒 子を用いて離散化したモデルにより近似している.さらに，粒子間の熱伝導及び，熱うく射を考慮している.本手法によれば，爆発火炎の 湧き出しを伴う上昇や，上昇気流後方に起こる気流の巻き込み現象などが表現可能である .レンダリングには，Z-バッファベースのボ リュームレンダリングを適用している．

Abstract

In the present paper, we propose a particle-based method for the visual simulation of explosive flames. This method consists of a numerical simulation method based on a fluid model described by discrete Lagrangian using particles and a rendering method for generating a CG animation from the movement data of the particles. This fluid model uses flame particles and air particles. The model calculates the buoyancy caused by the difference in temperature as the external force in the Navier-Stokes equations and approximates the viscous force and pressure via a discrete particle model. In addition, the heat conduction between particles and the heat radiation is taken into account. The proposed method realizes the representation of distinctive phenomena such as an ascending airflow with a quantity of explosive flame and a swirling airflow behind the ascending airflow. CG images are rendered using a Z-buffer based volume rendering method.

キーワード：爆発火炎, ビジュアルシミュレーション, 粒子ベースシミュレーション, 物理ベースモデル, ナビエ・ストークス方程式 Keywords: explosive flames, visual simulation, particle-based simulation, physics-based model, Navier-Stokes equations

\section{1.はじめに}

最近，炎，煙，および液体の運動などを対象とした，物 理ベースシミュレーションによるリアルなアニメーション 法が提案されてきている[1-10]. 本論文では , 粒子ベース シミュレーションによる爆発火炎のアニメーション法を提 案する.

物理現象の数值シミュレーションの分野では, 流体力学 の基本方程式であるナビエ・ストークス方程式（以下， $\mathrm{N} \cdot \mathrm{S}$ 方程式) を 3D メッシュて離散化する有限要素法に よって解析する手法が一般的である[1-10] . CG において， このような手法で流体を表現した例は多い. Foster と Metaxas による煙の表現[1]，Stam による安定した流体の解 法[2] , 衝撃波と構造物の破壊のシミュレーションとして, Neff と Fiume による例[3] , Mazarak らによる例[4] , Witting による水の圧力動乱とアニメのシーンへの統合の例[5] , Foster と Fedkiw によるレベルセット法を用い，流体形状の 表現を行った水の例 [6]，Stam による解法[2]を基に Vorticity Confinement 法と呼ばれる渦場を保つ力を加えた Fedkiw らによる煙の表現[7], Lamorlette と Foster によるス ペクトル理論を応用したアニメの制作環境のための炎の構 造的モデリングの例[8], Enright らによる砕け波を含め た，より複杂隹な水面を構築する手法[9], Nguyen らによる
固体と気体の燃料の化学反応を考慮した炎の例[10]があ る.

一方，本論文が目的とする“爆発”を表現する手法とし

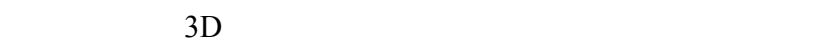
は, Yngve らによる流体の質量とエネルギーの輸送を donor-acceptor 法によって求めた手法[11]がある. また最 近, Feldman らによって, 粉塵爆発を生成する手法が提案 された[12].この手法では, gas model と particulate model を構築し，3D メッシュにおける流れの解析とシミュレー ションに追加される粒子との相互作用を考慮することで， 粉塵爆発をシミュレートしている.この手法は高速であ り，爆発の膨張が良く表現されている．しかしながら，表 現されている流体の振る舞いは単純な印象を受ける . ま た, Rasmussen らによって, 原子爆弾による大規模なキノ コ雲のアニメーションを生成することを目的とし , スペク トル理論の応用により，2D 流体シミュレーションによっ て得られたデータを $3 \mathrm{D}$ アニメーションへ拡張する手法も 提案されている[13].

一方，上記の 3D メッシュによる離散化とは異なるアプ ローチとして，水流や炎などの複雑な流体境界面を伴う現 象のアニメーションではラグランジアン記述である“粒子 ベースシミュレーション”が単純な手法として効果的であ る[14-20]. 光して , この粒子による離散化のアプローチを 
用いたシミュレーションは計算流体力学の分野でも活発に 研究されている[21,22] . また, 粒子ベースシミュレーショ ンでは流体境界面の可視化において, メタボールの密度分 布を適用するなど単純な手法が適用できる

運動シミュレーションの取り扱いの容易さと可視化の容 易さから, これまでもCGの分野においては, 粒子ベース の流体アニメーションに関する研究は数多くある.例え ば，Reeves による花火のような噴出火炎の例[14], Simsに よる滝の表現などの例[15]が挙げられる．しかしながら， これらは単純な質点の運動シミュレーションであり, 流体 の特徵である圧力や粘性は考慮されていない，弚のため， 噴出火炎や滝のような表現はできても, 連続体としての特 徵か溞く現れる流体の運動を十分に表現しきれていない． 乥れに対し，Chiba[16]らは粘性を考慮し，滝や水流を表現 した .この手法では対象としている粒子と关の周囲の粒子 との間で速度差の加重平均を取ることで粘性力を表現し た。乥して, Stam と Fiume は粘性を考慮し, Blob Warping と呼ばれる手法を用いて炎と煙を表現した[17] .一方， Chiba[18]らは粒子と渦場によって炎と煙の表現の手法を提 案したが，これは粘性を考慮していなかった．また， Bashforth と Yang が提案した爆発アニメーションシステム でも，粘性は考慮されていない[19,20] .このシステムは爆 発のシミュレーションのために粒子を移流と質量保存に用 い, 3D メッシュ上の各粒子数で圧力計算を行うが, 残念 ながら, 彼らの論文[19]とアニメーション[20]からはリア ルな爆発火炎を生成することができる手法かどうかを確認 することは難しい .

空気は動粘性率が低いため, 炎や煙の場合, 粘性力を考 慮することなく流体を表現した例もある[7,10,12-14,1820] . しかしながら, 高温, 高圧である爆発火炎などの現 象をシミュレートする場合，動粘性率は大きくなるため， 粘性力を考慮したほうがリアリティは向上する．

本論文では浮力, 粘性力, 熱伝導, 熱ふく射を考慮 し，粒子間力によって圧力を近似する爆発火炎の粒子ベー スシミュレーション法, ならびに, 粒子温度による色と不 透明度の定義に基づくレンダリング法を提案する．

粒子ベースシミュレーションとして, 数值流体力学の分 野において，SPH 法[21]や MPS 法[22]など, 粒子を単位と する離散化に基づく方法が開発されている.SPH 法では， カーネルの重ね合わせとして物理量 (密度と圧力) 分布を 導き, MPS 法では, 重み関数による粒子数密度をもとに得 られる圧力のポワッソン方程式 (連立方程式) を解いて， 圧力分布を求めている. 本モデルでは, 粒子間相互作用力 により圧力勾配を近似しており，これらの手法に比べて計 算が単純である。(例えば，筆者らの比較実験によれば， MPS 法に対して, 本手法の計算量は $1 / 200$ 程度であっ た.)

本手法によれば, 複雑な流体境界面の表現や, 粘性力を 考慮することで, 爆発火炎の丸みや内部からの湧き出す現 象が表現可能である . なお, 本提案手法の初期バージョン については文献[23]に, また本論文の一部は文献[24]に発 表している . 本論文でのバージョンでは計算効率性におい て, 初期バージョンのものより向上しており，また本論文 ではこれまでの文献では記載できなかったレンダリング手 法について詳細に述べている .

2. 粒子ベース爆発火炎モデル

ここでは爆発火炎の性質について触れ，粒子ベースシ ミュレーション法に考慮される物理現象を説明し, 兴のシ
ミュレーション方法を具体的に述べる．

\section{1 爆発火炎の性質}

爆発火炎の媒体は可燃性のガス，火薬，爆薬などであ り，燃焼・焼失の遷移状態を有する．ひとたび媒体の一部 が燃焼状態に遷移すると瞬時に媒体全体を燃焼状態に遷移 させ, 光の化学反応による高いエネルギーによって急激な 膨張を伴って上昇する . 急激な膨張は周囲の空気を圧縮さ せ，关の圧力差による圧力勾配の影響と速度差による粘性 力の影響によって，炎は内側から涌き出すように発達し， 炎境界では外側からの巻き込みが発生する. 爆発火炎は非 常に高温であるため, 周囲空気に対してのエントレインメ ントの効果も大きい. エントレインメントとは, 流体塊の へりにおいて温度が異なる流体間の混合が起こることで光 の部分の温度が下がる現象である.エントレインメントに よって暖められた空気は上昇気流を発生させる.さらに， 周囲に対して高温の流体は，熱ふく射による熱の損失が起 こる.また，炎は温度によって異なる色彩の光を発する． 高温な順に, 白 , 黄, 橙, 赤である。

本手法では，燃焼状態にある炎の塊を炎粒子，空気の塊 を空気粒子とした 2 流体の解析において, 浮力, 粘性力, 圧力と体積を表現する粒子間力, エントレインメント効果 と熱ふく射を考慮することによって, 爆発火炎特有の振る 舞いである, 炎粒子集団における内部からの湧き出しと炎 境界での巻き込みを実現している．ただし，本モデルで は, 炎と空気の間における化学的反応を考慮せず，炎粒子 は焼失しないものとしている .この制限によって，燃焼に よる反応熱，および反応熱による気体の膨張は考慮されな いので, 連続的に澎張するような火炎の表現において不十 分である.また, 炎, 煙の拡散現象も考慮していない，本 手法においてエントレインメント効果は粒子間の熱伝導に よってシミュレーションしている．また，レンダリングで は, 粒子の温度によって炎, 煙の色と不透明度を決定す る。

\section{2 粒子ベースシミュレーション法}

粒子ベースシミュレーション法では, 対象とする流体塊 を粒子で表現し, 粒子群によって流体の運動を表現する。 つまり，空気の塊を空気粒子，炎の塊を炎粒子として，こ れら粒子による離散的な力学モデルを作成し, 数値シミュ レーションを行う .

非圧縮性粘性流体の支配方程式である $\mathrm{N} \cdot \mathrm{S}$ 方程式と流 体の熱計算の方程式を以下に示す .

$$
\begin{aligned}
& \nabla \cdot u=0 \\
& \frac{\partial u}{\partial t}=-(u \cdot \nabla) u+v \nabla^{2} u-\nabla p+f \\
& \frac{\partial T}{\partial t}=-(u \cdot \nabla) T+\alpha \nabla^{2} T-\beta T^{4}
\end{aligned}
$$

ここで, $u, t, v, p, f, T, a, \beta$ は光れ攵れ, 速度， 時間, 動粘性率, 圧力, 外力, 温度, 温度伝達率, 熱心く 射率である.(1)式は質量保存、(2)式の右辺は光れ午れ， 移流項, 粘性項, 圧力項, 外力項, (3)式の右辺は乥れ光 れ，移流項，熱伝導項，熱ふく射項である. 粒子ベースシ ミュレーション法では, 粒子を用いることで質量は完全に 保存され，移流項は粒子の持つ慣性速度力対応する．さら に本手法では粘性項をモデル化し, 粒子間力によって圧力 
項の実現を試みることによって, 支配方程式の各項に対応 した近似的な離散化となっている.また，外力として浮力 を考慮し，熱伝導，熱ふく射をモデル化する．

\section{3 粒子に考慮される物理現象}

本論文では爆発火炎の実現のために浮力, 粘性力, 粒子 間力, 熱伝導, 熱ふく射を考慮した . 粒子に働く合力 $F$ は 以下のように表される .

$$
F=f_{\text {buo }}+f_{\text {vis }}+f_{\text {int }}
$$

ここで $f_{\text {buo }}, f_{\text {vis }}, f_{\text {int }}$ は光れぞれ, 浮力, 粘性力, 粒子間力 である.ただし，浮力 $f_{\text {buo }}$ は熱伝導 $T_{\text {con }}$ と熱ふく射 $T_{\text {rad }}$ に よって更新される温度をもとにして計算される。

$$
f_{\text {buo }}=f\left(T_{\text {con }}, T_{\text {rad }}\right)
$$

これらの力を全ての粒子において計算する．以下に关れ光 れの物理現象のモデル化について詳細に述べる .

\section{3. 1 浮力}

ここでは爆発火炎のシミュレーションにおいて上昇気流 を発生させる浮力の計算について説明する . 浮力計算は以 下のように行う.

$$
f_{\text {buo }}=c_{\text {buo }} m g \frac{T-T_{\text {env }}}{T_{\text {env }}}
$$

ここで $c_{b u o}, m, g, T, T_{\text {env }}$ は光れ光れ, 浮力を調整するた めの任意の係数, 粒子質量, 重力加速度, 粒子温度, 環境 温度である。

\section{3.2 粘性力}

粘性力の表現には, 水流のシミュレーション[16]のため に筆者らの一部が提案した粒子による離散化モデルを用い る.なお，同樣の粒子による離散化が流体シミュレーショ ンの分野で提案されている[22] .

$\mathrm{N} \cdot \mathrm{S}$ 方程式における粘性項は $\partial u / \partial t=v \nabla^{2} u$ で表される . この粘性項の計算を粒子ベースシミュレーションでは近傍 粒子との距離に関する速度差の加重平均により実現する . この加重平均とは粒子間距離によって重み付けを行い, 対 象粒子に近い粒子ほど粒子速度に影響を及ぼしやすくする 手法である .ここで加重平均に用いる加重関数は正規分布 をもとに作成した以下の式を用いる .

$$
\begin{aligned}
& \omega\left(d_{r}\right)=\left\{\begin{array}{cc}
0 & \left(d_{r}>1.0\right) \\
\exp \left(-5 d_{r}{ }^{2}\right) & \left(d_{r} \leq 1.0\right)
\end{array}\right. \\
& d_{r}=d /\left(r_{i}+r_{j}\right)
\end{aligned}
$$

ここで, $d, r_{n}$ はとれ炎れ粒子間距離，粒子 $n$ の粒子半径 である. 粒子半径 $r_{n}$ は以下の式を用いて求める.

$$
\begin{aligned}
& r_{n}=\sqrt[3]{3 V_{n} / 4 \pi} \\
& V_{n}=k m_{n} T_{n}
\end{aligned}
$$

ここで， $V_{n}, m_{n}, T_{n}$ ，は光れ光れ，粒子 $n$ の体積，質量， 温度である . 係数 $k$ は体積を調整するための任意の係数で ある .

(7) 式の加重関数を用いて粘性項をモデル化すると，粒 子i に対する粘性力は以下のように書ける .

$$
f_{v i s}=c_{v i s} \sum_{j \neq i}\left[\left(u_{j}-u_{i}\right) \omega\left(d_{r}\right)\right]
$$

ここで， $c_{v i s}, u_{n}$ は光れ光れ，本モデルにおける動粘性率， 粒子 $n$ の速度である.

\subsection{3 粒子間力}

$\mathrm{N} \cdot \mathrm{S}$ 方程式における圧力項は $\partial u / \partial t=-\nabla p$ で表される .こ れは圧力の勾配で表され，本モデルではこの力を粒子間力 によって以下のようにモデル化する .

粒子の体積を粒子間に働く斥力の存在を仮定することに より実現する .この体積は粒子をシミュレーション空間に 均等に分布させるように働き, また, シミュレーション空 間に満たされる十分な個数の初期配置空気粒子とシミュ レーションの過程で発生させる炎粒子との相互作用によ り，局所的な圧力差を発生させる. 本モデルにおける粒子 間力は以下のようである .

\section{・2つの粒子間の距離が光れらの半径の和より小さい場 合は斥力が発生する .}

この規則を満たすために, 粒子 $i$ と粒子 $j$ の間に発生す る斥力に用いる関数には, 正規分布をもとに作成した以下 の式を用いる .

$$
f_{\text {int }}=\left\{\begin{array}{cc}
0 & \left(d_{r}>1.0\right) \\
c_{\text {int }} \exp \left(-5 d_{r}{ }^{2}\right) & \left(d_{r} \leq 1.0\right)
\end{array}\right.
$$

ここで， $c_{i n t}$ は粒子間力係数である．

\section{3 .4 熱伝導}

ここでは熱伝導のモデル化について述べる . 本モデルに おける熱伝導はエントレインメント効果の簡易的実現とし て用いている。

熱伝導の方程式は $\partial T \partial t=\alpha \nabla^{2} T$ で表される．これは温度 の 2 階偏微分で表され, 粘性項と同樣の手法でモデル化す ることができる．熱伝導をモデル化すると粒子ｉに対する 熱伝導は以下のように書ける .

$$
T_{c o n}=c_{c o n} \sum_{j \neq i}\left[\left(T_{j}-T_{i}\right) \omega\left(d_{r}\right)\right]
$$

ここで,$c_{c o n}$ は本モデルにおける温度伝達率である．

2. 3. 5 熱ふく射

ここでは，熱ふく射のモデル化について述べる．熱ふく 射の方程式は $\partial T / \partial t=-\beta T^{4}$ で表される .この熱うく射による 周囲への温度の損失を以下のようにモデル化する .

$$
T_{r a d}=-c_{r a d}\left(\frac{T-T_{e n v}}{T_{\max }-T_{e n v}}\right)^{4}
$$


ここで， $c_{r a d}$ は本モデルにおける熱うく射率である．ま た， $T_{\max }$ はシミュレーションにおける最大温度であり，炎 粒子の初期設定温度が用いられる。

\section{4 境界条件}

ここでは本モデルにおける境界条件について述べる． 物体境界条件として, 粒子と物体との境界条件を次のよ うに定める . 粒子とポリゴンで表される物体表面との衝突 判定を行い, 物体表面では粒子は通過することができず， その表面を滑るものとする.また, 粒子と物体表面との距 離に応じて, 加重関数を用いて粘性力と熱伝導を考慮す る.

大気境界条件として, シミュレーション空間の外側境界 面において, 境界条件を次のように定める. 境界に達した 場合, 炎粒子は消滅し, 空気粒子は温度を環境温度に再設 定され，谷の表面を滑るものとする．

\section{5 粒子探索法}

粒子間力, 粘性力, 熱伝導の計算では, 対象粒子の近傍 の粒子を探索する処理が行われる . 本モデルではボクセル を用いた空間分割による粒子探索法を用いた . ボクセル幅 はシミュレーションにおける全粒子の最大直径が用いられ る 。

\section{6 タイムステップ算出}

計算の効率化のため, 各計算ステップの粒子の最大速度 $u_{\max }$ と最小直径 $2 r_{\text {min }}$ を考慮して, シミュレーションのタイ ムステップ $\Delta t$ を計算ステップごとに可変にすることとし た . タイムステップを算出する式を以下のように定める .

$$
\frac{u_{\max } \Delta t}{2 r_{\min }} \leq 1.0
$$

上式の左辺はクーラン数であり，粒子の最小直径に対する 粒子の最大速度によるタイムステップ間の移動距離の割合 を示す. 数値流体力学の分野における粒子ベースシミュ レーションでは, 右辺の值はより小さい值が用いられ, シ ミュレーションの正確性が求められる.しかしながら，リ アルなアニメーション生成を目的とした本提案手法では， シミュレーションの効率性に重点をおくこととし , シミュ レーションが破綻しない程度でタイムステップをできるだ け大きくとれるように值を定めた . 実験によって確かめら れた値は 1.0 である.これにより, タイムステップを固定 したシミュレーションに対して，図 7 に示すシミュレー ション例の場合，最大で $30.4 \%$, 平均で $10.1 \%$ 計算時間 が短縮された .なお, 本モデルの時間差分スキームには1 次精度のオイラー陽解法を用いている。

\section{3.レンダリング}

1節で述べた 3D メッシュによる離散化に基づくシミュ レーションでは, シミュレーションによる速度場, 密度場 の算出と共に流体の形状を視覚化するマーカー粒子やレベ ルセット法を用いてレンダリングを行う.一方，本提案手 法が用いる粒子ベースシミュレーションにおけるレンダリ ングでは, シミュレーションによって得られた粒子の位置 データを用いて直接レンダリングを行う簡便な方法が適用 できる .
本手法では，画像の生成において，OpenGL による Z バッファレンダリングに基づく 3D テクスチャ（ボリュー ムデータ) のレンダリングを行った . 粒子の温度に応じた 色と不透明度を 3D テクスチャに設定し , a ブレンディン グによって，視点から遠い順に背景に描き込んでいくこと で半透明ボリュームのレンダリングを行った .この手法 は，レイキャスティング型のボリュームレンダリングに比 ベ, 交差判定とボクセルの 3D サンプリングを行わないた め，高速に実行できる .

\section{1 レンダリングにおける粒子サイズの決定}

本モデルでは, 炎, 煙の拡散現象を考慮しないものと し，温度が下がった炎粒子のサイズを拡大することで煙の 広がりを表現する.レンダリングにおける炎粒子のサイズ を決定する式を以下に示す。

$$
r_{r e n}= \begin{cases}r\left(1.0+\frac{T_{t h r}-T}{T_{t h r}-T_{s i z}}\right) & \left(T<T_{t h r}\right) \\ r & \left(T \geq T_{t h r}\right)\end{cases}
$$

ここで, $r_{r e n}, r, T_{t h r}, T, T_{s i z}$ は光れ光れ，レンダリングの ための粒子半径, シミュレーションによって得られた粒子 半径, 閾值, 粒子温度, 粒子半径を調整するための任意の 係数である。

\section{2 粒子温度による色と不透明度の定義}

本モデルではシミュレーションにおいて炎と煙を区別す ることなく，炎粒子として扱った．レンダリングにおい て, 煙を含めた表現を可能とするため, 温度が低い粒子に は煙としての色と不透明度, 温度が高い粒子には炎として の色と不透明度を与える.これらの実現のため，色 RGB と不透明度 $A$ の決定において, 以下の式を用いることで実 現した。

$$
\begin{aligned}
& \mathrm{R}=\left(5.4 T / T_{\max }-2.5\right) / 1.5 \\
& \mathrm{G}=\left(5.4 T / T_{\max }-3.0\right) / 3.0 \\
& \mathrm{~B}=\left(5.4 T / T_{\max }-4.0\right) / 3.0 \\
& A=1-\exp \left(-\left(0.18 T / T_{\max }\right)^{2}\right)
\end{aligned}
$$

ただし， $0.0 \leq \mathrm{R} \leq 1.0 ， 0.0 \leq \mathrm{G} \leq 1.0 ， 0.0 \leq \mathrm{B} \leq 0.9$ ， $0.0 \leq A \leq 1.0$ であるものとする .ここで $T_{\max }$ はシミュ レーションにおける最大温度であり, 炎粒子の初期設定温 度が用いられる.この RGB と $A$ の値を以下に示すボ リュームデータに反映する。

\section{3 ボリュームデータ}

本手法では，光れ光れの粒子にマッピングする $3 \mathrm{D}$ テク スチャ (ボリュームデータ) は $4 \times 4 \times 4$ 個のボクセルの集合 で与える.ボクセルの一辺の長さは $r_{r e n} / 4$ である . このボ クセル值 $D$ には, 重み付けによって中心部の数值を高くし た球状の分布にノイズを加えたものを用いた .

粒子温度によって得られた色と不透明度, およびボクセ ル值によって, 最終的に OpenGL に渡されるボリューム デー夕は, 色 RGB, 不透明度 $A * D$ である. 図1(b)に単 一の粒子をレンダリングした画像を示す。 
4. 挙動シミュレーション

ここでは, 各係数の違いによる効果を示すために挙動シ ミュレーションを示す.シミュレーション空間には初期配 置として, 粒子間力によって圧力を実現するために, 粒子 間力が互いに働く距離で十分な個数の空気粒子を配置す る.シミュレーション空間の外側境界上に大気境界条件を 適用し, シミュレーション空間底部には地面があるものと して物体境界条件を適用する。

図 1 にシミュレーションの比較の基となる参照シミュ レーション例を示す．

図 2 は上図から浮力係数を $0.5,2.0$ とした際のシミュ レーションである . 浮力係数を大きくするほど, 強い上昇 気流が発生する。

図 3 は上図から動粘性率を $0.0 ， 1.0$ とした際のシミュ レーションである . 動粘性率を大きくするほど , 炎粒子集 団は丸みを帯びるが, 炎粒子の湧き出しや巻き込みといっ た運動も阻害される。

図 4 は上図から粒子間力係数を $5.0,100.0$ とした際のシ ミュレーションである . 值を 5.0 とした場合 , 斥力が弱す ぎるため, 炎粒子の挙動を押さえ込むことができず, 散乱 する.また值を 100.0 とした場合, 爆発火炎の膨張, 収縮 の挙動が顕著に見られるが, 斥力が強すぎるため, シミュ レーション後半において, 粒子集団が押しつぶされ, まと まりすぎる印象を受ける

図 5 は上図から温度伝達率を $0.0,1.0$ とした際のシミュ レーションである.熱伝導によって, 炎粒子集団は外側か ら冷えていく . また, 温度伝達率を大きくするほど炎粒子 は冷えやすい.

図 6 は上図から温度伝達率を $0.0,5000.0$ とした際のシ ミュレーションである.熱うく射によって , シミュレー ション空間内に発生している炎粒子は時間を追って冷えて いく．また，熱うく射率を大きくするほど，炎粒子は冷え やすい．

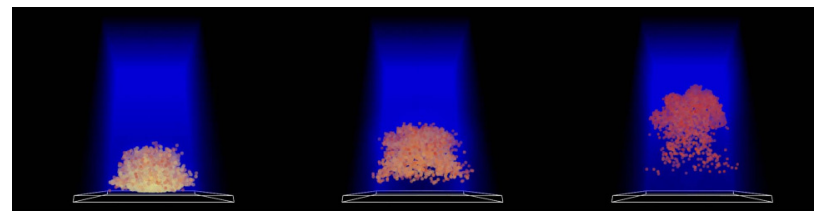

(a) シミュレーションの簡易表示

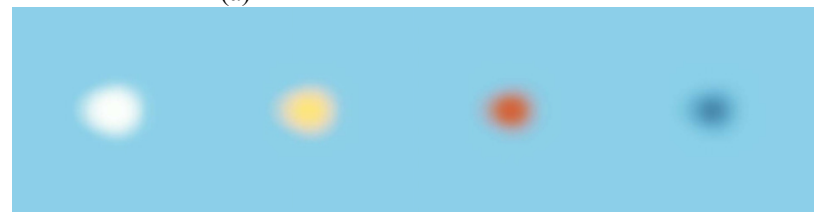

(b) 単一粒子のレンダリング画像

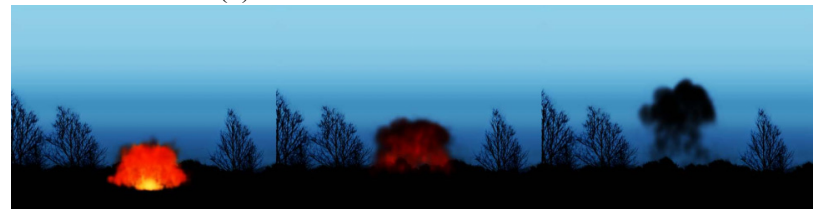

(c) レンダリング画像

図1，参照シミュレーション：

図(a)において, 黄色と赤の点は炎粒子, 青は空気粒子群を示す . 図(b)において，左から温度は $2173 ， 2100 ， 1500,900$ である.た だし, 図(c)と比較して, 不透明度を 5 倍, 粒子のサイズを 20 倍 とした . 図(a)，(c)に用いたパラメータは $c_{\text {buo }}=1.0, c_{\text {vis }}=0.1, c_{i n t}=$ $60.0, c_{c o n}=0.5, c_{\text {rad }}=1000.0$ である.

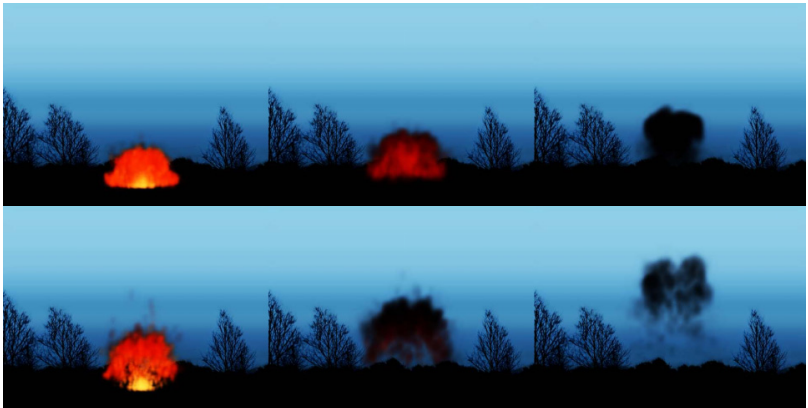

図2. 浮力係数の違いにおける 効果について :

上図 $c_{\text {buo }}=0.5$, 下図 $c_{\text {buo }}=2.0$

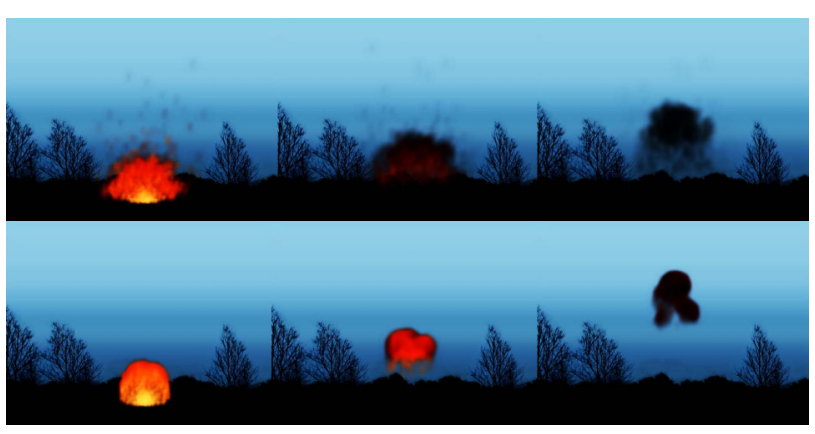

図3．動粘性率の違いにおける効果について：

上図 $c_{v i s}=0.0$,下図 $c_{v i s}=1.0$

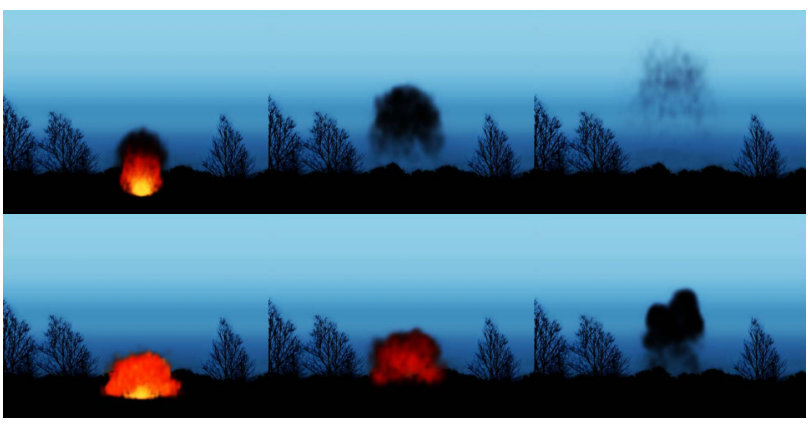

図4．粒子間力係数の違いにおける効果について :

上図 $c_{i n t}=5.0$,下図 $c_{i n t}=100.0$

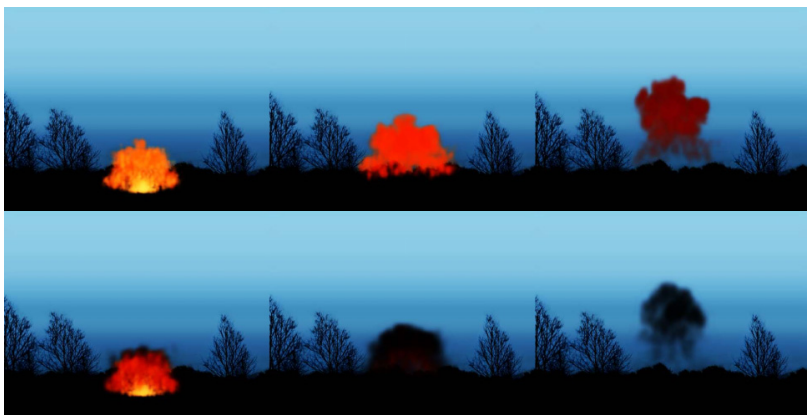

図5 . 温度伝達率の違いにおける効果について :

上図 $c_{c o n}=0.0$, 下図 $c_{c o n}=1.0$

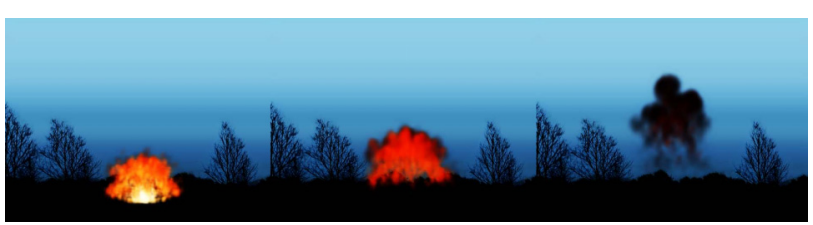




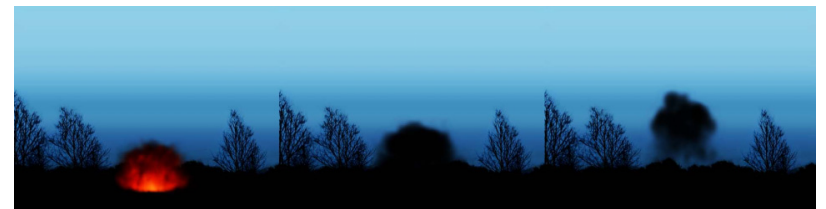

図6．熱ふく射率の違いにおける効果について：

上図 $c_{\text {rad }}=0.0$, 下図 $c_{\text {rad }}=5000.0$

\section{5. 実験結果}

シミュレーション例を図 7 に示す . なお , 本論文に示す

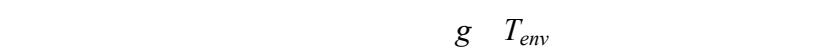
の值を用いた .

図 7 (a)，(b)は空気粒子を 2055168 個を用いている . 空気 粒子の直径を 1.0 とした時, シミュレーション空間の相対 的なサイズ $87.0 \times 144.2 \times 87.0$ において，相対的な半径 5.8 の 半球内の任意の点において, 相対的な直径 2.0 の炎粒子を シミュレーションの想定時間において，20000 個／秒の割 合で 0.5 秒間発生させたものを異なる係数で行ったシミュ レーションである.ここで, 粒子探索に用いたボクセルの 解像度は $45 \times 74 \times 45$ である。

図 7 (c)，(d)は空気粒子を 3022848 個を用いている.空気 粒子の直径を 1.0 とした時, シミュレーション空間の相対 的なサイズ $115.8 \times 158.8 \times 87.0$ において，3 箇所に設定した 相対的な半径 5.8 の半球内の任意の点において, 相対的な 直径 2.0 の炎粒子をシミュレーションの想定時間におい て , 20000 個/秒の割合で 0.5 秒間発生させたものを異な るタイミング, および係数で行ったシミュレーションであ る.ここで, 粒子探索に用いたボクセルの解像度は $60 \times 81 \times 45$ である .

図 7 (e)は空気粒子を 3425280 個を用いている.空気粒子 の直径を 1.0 とした時, シミュレーション空間の相対的な サイズ $144.6 \times 144.2 \times 87.0$ において，2 箇所に設定した相対 的な半径 5.8 の半球内の任意の点において, 相対的な直径 2.0 の炎粒子をシミュレーションの想定時間において， 10000 個/秒の割合で 1.0 秒間, 初速度を与えて発生させ ることで爆発火炎の衝突を行ったシミュレーションであ る. 粒子探索に用いたボクセルの解像度は $74 \times 74 \times 45$ であ る.

図 7 (f)は空気粒子を 272136 個を用いている. 空気粒子 の直径を 1.0 とした時, シミュレーション空間の相対的な サイズ $62.7 \times 30.9 \times 127.0$ において, 相対的な半径 2.1 の半球 内の任意の点において, 相対的な直径 2.0 の炎粒子をシ ミュレーションの想定時間において，50000 個／秒の割合 で 1.0 秒間, 通路を設定した閉空間で発生させたシミュ レーションである . 粒子探索に用いたボクセルの解像度は $32 \times 16 \times 65$ である .

シミュレーションのパラメータとデータを表 2 , 表 3 に 示す.これらのシミュレーションは $\mathrm{P} 4-2.4 \mathrm{GHz}$ の CPU , 1GB のメモリを用いて行われた . なお, これらのシミュ レーション例のムービーを付属のファイルに収録してい る.

\section{表1。計算パラメータ:}

重力加速度 $g$, 環境温度 $T_{e n v}$, 体積を調整するための係数 $k$

\begin{tabular}{ccc}
\hline$g$ & $T_{e n v}$ & $k$ \\
\hline 9.8 & 288.0 & $3.0 \times 10^{-3}$ \\
\hline
\end{tabular}

\section{6. おわりに}

本論文では爆発火炎の粒子ベースビジュアルシミュレー ション手法の開発として, 粒子に対し, 浮力, 粘性力, 熱 伝導、熱うく射の効果を考慮し，粒子間力によって体積と 圧力勾配を表現する方法を提案した．これにより，爆発火 炎の湧き出しを伴う上昇や，上昇気流後方に起こる気流の 巻き込み現象, 複杂隹な流体境界面の表現が可能であること を示した．また境界条件を設定することで, 通路のような 閉空間でのシミュレーションも可能であることも確認され た.

しかしながら、現在のモデルでは炎粒子に対して，可視 化に貢献しない非常に多数の空気粒子を使用しなければな らないという問題がある.計算速度の改善のため，より少 ない空気粒子で同樣の効果が得られるモデルの開発が望ま れる .

謝辞

粒子による流体シミュレーション法の開発において, 東 京大学越塚先生の粒子法に関するご研究に激励されるとこ ろが大きい.なお, 本研究の一部は, 通信・放送機構「地 域提案型研究制度」に係わる研究開発課題による。

\section{参考文献}

[1] N. Foster and D. Metaxas. Modeling the Motion of a Hot, Turbulent Gas. In Proceedings of ACM SIGGRAPH 97, Computer Graphics Proceedings, Annual Conference Series, 181-188, 1997.

[2] J. Stam. Stable Fluid. In Proceedings of ACM SIGGRAPH 99 , Computer Graphics Proceedings, Annual Conference Series, 121-128, 1999.

[3] M. Neff and E. Fiume. A Visual Model For Blast Waves and Fracture. In Graphics Interface '99, 193-202, 1999.

[4] O. Mazarak, C. Martins and J. Amanatides. Animating Exploding Objects. In Graphics Interface '99, 211-218, 1999.

[5] P. Witting. Computational Fluid Dynamics in a Traditional Animation Environment. In Proceedings of ACM SIGGRAPH 99, Computer Graphics Proceedings, Annual Conference Series, 129-136, 1999.

[6] N. Foster and R. Fedkiw. Practical Animation of Liquids. In Proceedings of ACM SIGGRAPH 2001, Computer Graphics Proceedings, Annual Conference Series, 23-30, 2001.

[7] R. Fedkiw, J. Stam and H. Jensen. Visual Simulation of Smoke. In Proceedings of ACM SIGGRAPH 2001, Computer Graphics Proceedings, Annual Conference Series, 15-22, 2001.

[8] A. Lamorlette and N. Foster. Structual Modeling of Flames for a Production Environment. In Proceedings of ACM SIGGRAPH 2002, Computer Graphics Proceedings, Annual Conference Series, 729-735, 2002.

[9] D. Enright, S. Marschner and R. Fedkiw. Animation and Rendering of Complex Water Surfaces. In Proceedings of ACM SIGGRAPH 2002, Computer Graphics Proceedings, Annual Conference Series , 736-744, 2002.

[10] D. Nguyen, R. Fedkiw and H. Jensen. Physically Based Modeling and Animation of Fire. In Proceedings of ACM SIGGRAPH 2002, Computer Graphics Proceedings, Annual Conference Series, 721-728, 2002.

[11] G. Yngve, J. O'Brien and J. Hodgins. Animating Explosion. In Proceedings of ACM SIGGRAPH 2000, Computer Graphics Proceedings, Annual Conference Series, 29-36, 2000.

[12] B. E. Feldman, J. F. O’Brien and O. Arikan. Animating Suspended Particle Explosions. In Proceedings of ACM SIGGRAPH 2003, Computer Graphics Proceedings, Annual Conference Series, 708-715, 2003.

[13] N. Rasmussen, D. Q. Nguyen, W. Geiger, and R. Fedkiw. Smoke Simulation For Large Scale Phenomena. In Proceedings of ACM SIGGRAPH 2003, Computer Graphics Proceedings, Annual Conference Series, 703-707, 2003.

[14] W. Reeves. Particle System - A Technique for Modeling a Class of Fuzzy Objects. In Proceedings of ACM SIGGRAPH 83, Computer Graphics Proceedings, Annual Conference Series, 359-376, 1983. 
[15] K. Sims. Particle Animation and Rendering Using Data Parallel Computation. In Proceedings of ACM SIGGRAPH 90, Computer Graphics Proceedings, Annual Conference Series, 405-413, 1990.

[16] N. Chiba, S. Sanakanishi, K. Yokoyama, I. Ootawara, K. Muraoka and N. Saito. Visual Simulation of Water Currents Using a Particle-based Behavioural Model. In The Journal of Visualization and Computer Animation, 6,3,155-171, 1995.

[17] J. Stam and E. Fiume. Depicting Fire and Other Gaseous Phenomena Using Diffusion Processes. In Proceedings of ACM SIGGRAPH 95, Computer Graphics Proceedings, Annual Conference Series, 129-136, 1995.

[18] N. Chiba, K. Muraoka, H. Takahashi and M. Miura. Twodimensional Visual Simulation of Flames, Smoke and the Spread of Fire. In The Journal of Visualization and Computer Animation, 5,1,37-54, 1994.

[19] B. Bashforth and Y. H. Yang. Physics-Based Explosion Modeling. In Graphical Models, 63, 21-44, 2001.
[20] http://www.cs.usask.ca/research/research_groups/vision/projects /explosions/

[21] R. A. Gingold and J. J. Monaghan. Kernel Estimates as a Basis for General Particle Methods in Hydrodynamics. In Journal of Computational Physics, 46, 429-453, 1988.

[22] S. Koshizuka and Y. Oka. Moving-Particle Semi-implicit Method for Fragmentation of Incompressible Fluid. In Nuclear Science and Engineering, 123, 145-158, 1996.

[23] 竹下大樹，太田真，田村真知子，藤本忠博，村岡一信，千葉 則茂 . 爆発火炎の粒子ベースビジュアルシミュレーション法 . 第 18 回 NICOGRAPH 論文コンテスト論文集, 115-120,2002 年 10 月

[24] D. Takeshita, S. Ota, M. Tamura, T. Fujimoto, K. Muraoka, N. Chiba. Particle-based Visual Simulation of Explosive Flames. In Pacific Graphics 2003 Proceedings, 482-486, October 2003

表2. シミュレーションパラメータ:

空気粒子質量 $m_{a}$, 炎粒子質量 $m_{f}$, 空気粒子温度 $T_{a}$, 炎粒子温度 $T_{f}$, 浮力係数 $c_{b u o}$, 動粘性率 $c_{v i s}$, 粒子間力係数 $c_{i n t}$, 温度伝達率 $c_{c o n}$, 熱了. く射率 $c_{r a d}$, レンダリング時の粒子サイズを調整するための閾值 $T_{t h r}$, レンダリング時の粒子サイズを調整するための係数 $T_{s i z}$

\begin{tabular}{|c|c|c|c|c|c|c|c|c|c|c|c|}
\hline \multirow{2}{*}{ シミュレーション } & \multicolumn{9}{|c|}{ シミュレーションパラメータ } & \multicolumn{2}{|c|}{ レンダリングパラメータ } \\
\hline & $m_{a}$ & $m_{f}$ & $T_{a}$ & $T_{f}$ & $c_{\text {bио }}$ & $c_{v i s}$ & $c_{\text {int }}$ & $c_{c o n}$ & $c_{\text {rad }}$ & $T_{t h r}$ & $T_{s i z}$ \\
\hline 図 7 (a) & 0.025 & 0.025 & 288.0 & 2173.0 & 0.5 & 0.1 & 15.0 & 0.5 & 1000.0 & 2000.0 & 1500.0 \\
\hline 図 7 (b) & 0.025 & 0.025 & 288.0 & 2173.0 & 0.5 & 0.5 & 20.0 & 0.5 & 1000.0 & 2000.0 & 1500.0 \\
\hline 图 7 (c) & 0.025 & 0.025 & 288.0 & 2173.0 & 0.5 & 0.2 & 15.0 & 0.5 & 1000.0 & 2000.0 & 1500.0 \\
\hline 図 7 (d) & 0.025 & 0.025 & 288.0 & 2173.0 & 0.5 & 0.1 & 15.0 & 0.5 & 1000.0 & 2000.0 & 1500.0 \\
\hline 図 7 (e) & 0.025 & 0.025 & 288.0 & 2173.0 & 0.5 & 0.1 & 15.0 & 0.5 & 1000.0 & 2000.0 & 1500.0 \\
\hline 図 7 (f) & 0.0005 & 0.0005 & 288.0 & 2173.0 & 0.1 & 0.03 & 3.0 & 0.9 & 1000.0 & 2000.0 & 1500.0 \\
\hline
\end{tabular}

表3．シミュレーションデータ

\begin{tabular}{l|ccccc}
\hline シミュレーション & 炎粒子数 & 空気粒子数 & $\begin{array}{c}\text { シミュレーション空間サイズ } \\
\text { (空気粒子直径を } 1.0 \text { とした場合) }\end{array}$ & $\begin{array}{c}\text { ボクセル解像度 } \\
\text { (粒子探索用) }\end{array}$ & $\begin{array}{c}\text { シュレーション } \\
\text { 想定時間 }\end{array}$ \\
\hline 図 7 (a) & 10000 & 2055168 & $87.0 \times 144.2 \times 87.0$ & $45 \times 74 \times 45$ & 5.0 \\
図 7 (b) & 10000 & 2055168 & $87.0 \times 144.2 \times 87.0$ & $45 \times 74 \times 45$ & 5.0 \\
図 7 (c) & 30000 & 3022848 & $115.8 \times 158.8 \times 87.0$ & $60 \times 81 \times 45$ & 7.5 \\
図 7 (d) & 30000 & 3022848 & $115.8 \times 158.8 \times 87.0$ & $60 \times 81 \times 45$ & 7.5 \\
図 7 (e) & 20000 & 3425280 & $144.6 \times 144.2 \times 87.0$ & $74 \times 74 \times 45$ & 5.0 \\
図 7 (f) & 50000 & 272136 & $62.7 \times 30.9 \times 127.0$ & $32 \times 16 \times 65$ & 1.2 \\
\hline
\end{tabular}

\begin{tabular}{cc}
\hline 総ステップ数 & $\begin{array}{c}\text { 計算時間 } \\
\text { [秒/ステップ] }\end{array}$ \\
\hline 348 & 24.8 \\
388 & 24.4 \\
788 & 37.1 \\
680 & 39.3 \\
490 & 41.4 \\
1179 & 4.1 \\
\hline
\end{tabular}


芸術科学会論文誌 Vol.3 No.2 pp.159-167
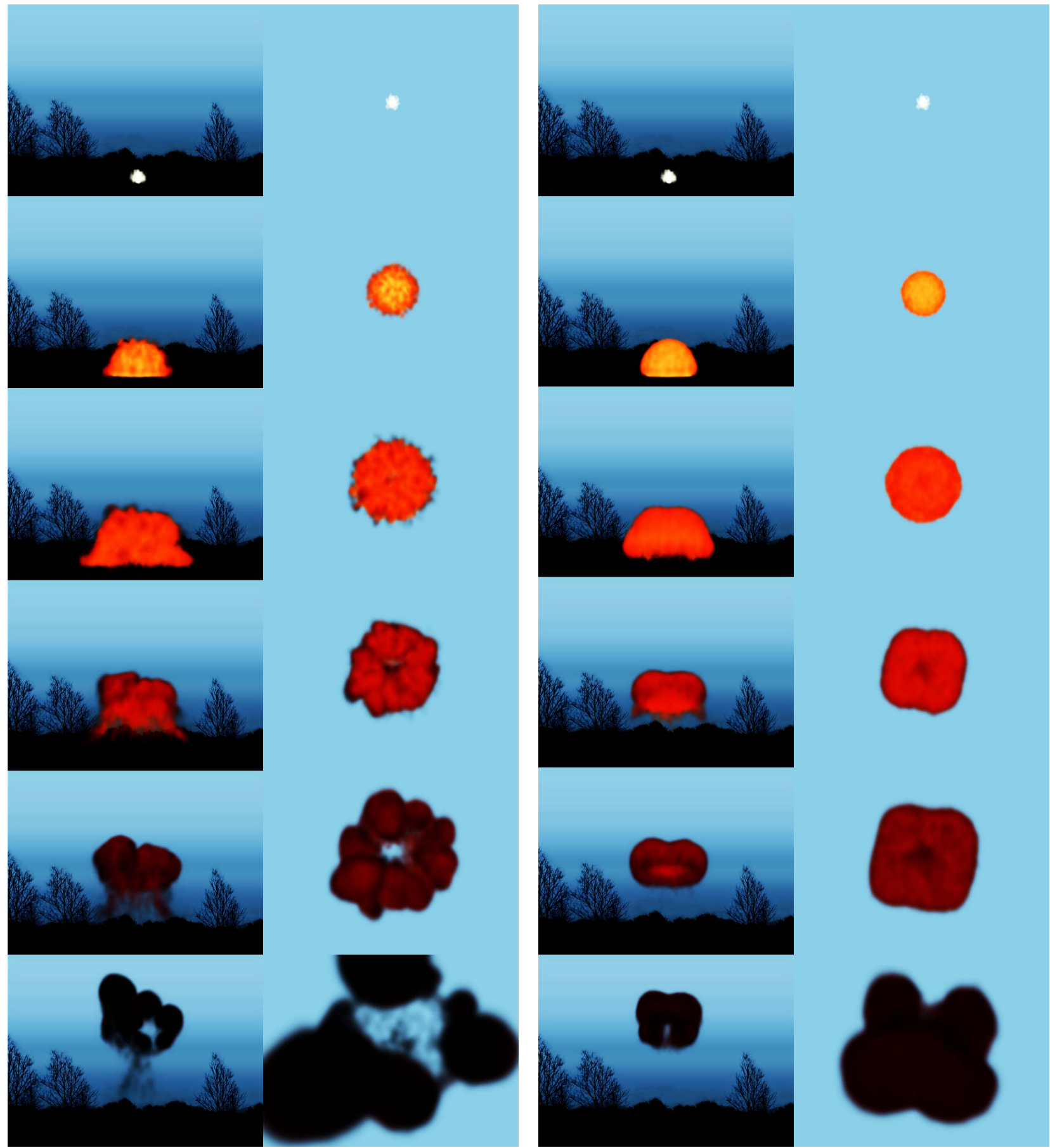

(a) 爆発火炎 1

(b) 爆発火炎 2 

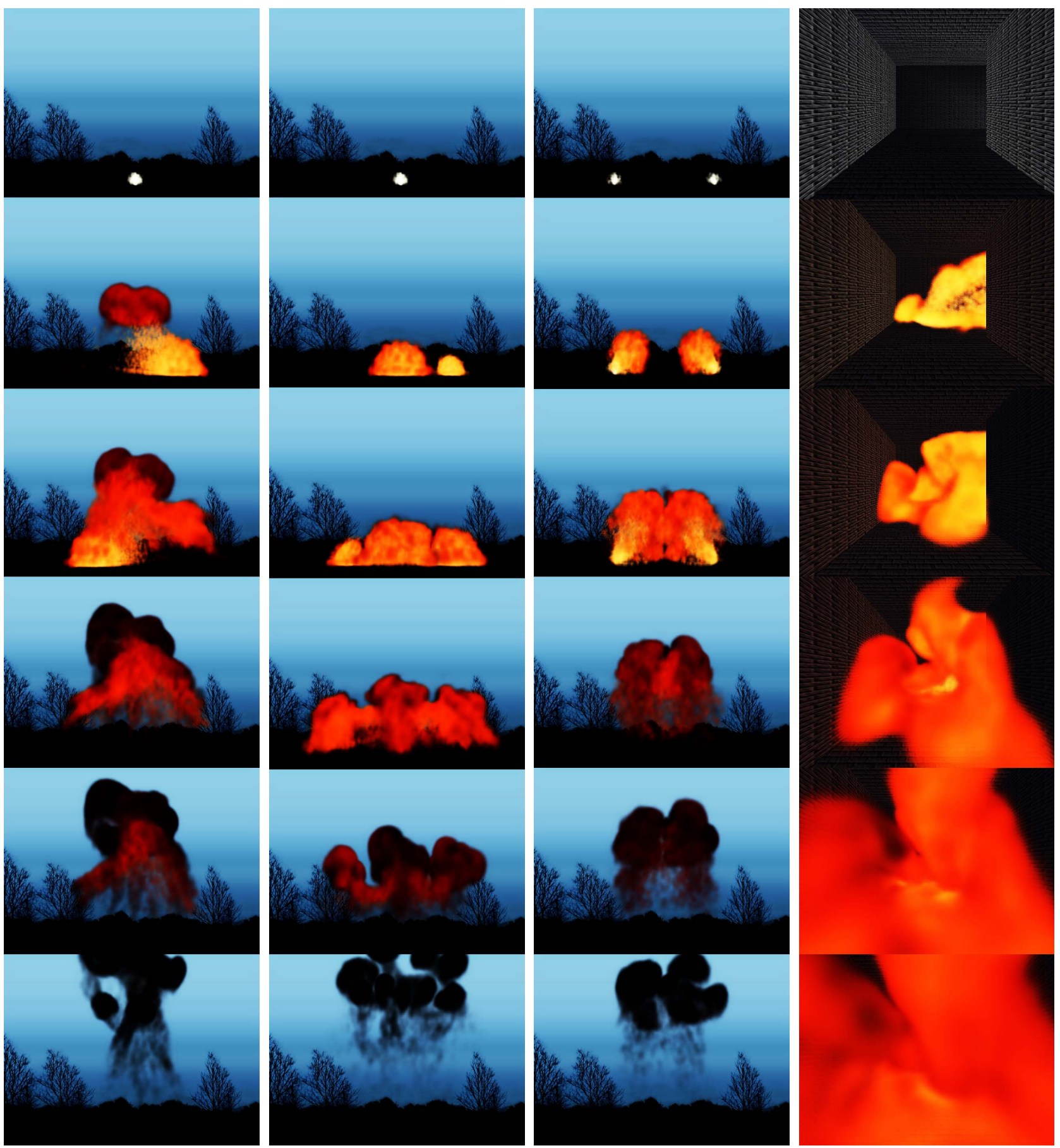

(c) 複数の爆発火炎 1

(d) 複数の爆発火炎 2

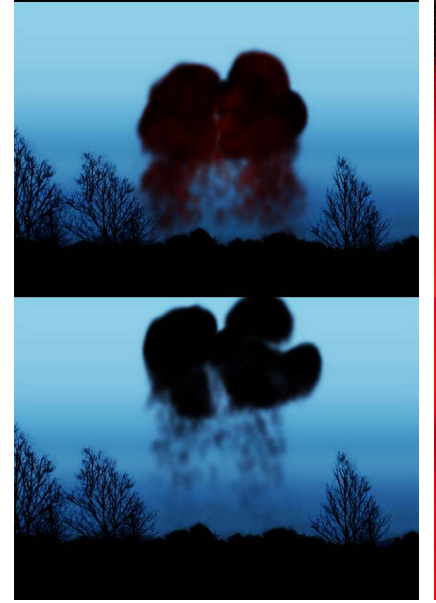

(e) 爆発火炎の衝突

(f) 通路における爆発火炎

図7.シミュレーション例:

図(a)，(b)，(e)は上図から 0,0.3，1，2，3，5 秒後の結果，図(c)は上図から $0 ， 2.3 ， 3.3,4.6,5.3,7.5$ 秒後の結果，図(d)は上図から 0 ， $0.3,0.6,1.6,3,7.5$ 秒後の結果，図(f)は上図から $0,0.23,0.46,0.69,0.92,1.2$ 秒後の結果を示す 